\title{
Occurrence of Sustained Droughts in the Interior Pacific Northwest (A.D. 1733-1980) Inferred from Tree-Ring Data
}

\author{
PAUL A. KNAPP \\ Department of Anthropology and Geography, Georgia State University, Atlanta, Georgia \\ Peter T. Soulé \\ Department of Geography and Planning, Appalachian State University, Boone, North Carolina \\ HENRI D. GRISSINO-MAYER \\ Department of Geography, University of Tennessee, Knoxville, Tennessee
}

(Manuscript received 21 January 2003, in final form 7 June 2003)

\begin{abstract}
The occurrence of moderate and severe sustained droughts in the interior Pacific Northwest (PNW) from 1733 to 1980 was mapped using 18 western juniper (Juniperus occidentalis var. occidentalis Hook.) tree-ring chronologies. The frequency and duration of both moderate and severe sustained droughts are substantially greater in the northwest region of the interior PNW. Thus, this area is identified as a drought core region. These droughts are chiefly attributed to the presence of a Pacific blocking high off the NW coast that is associated with significant reductions in cool season precipitation. Specifically, the impacted northwest region lies within a transition zone between the fluxes of marine airflow during the cool season months and interior air during the warm season months. The waxing and waning of the boundaries of this transition zone particularly affect western juniper trees growing in this region. During years in which a blocking high is present, marine airflow is substantially reduced, exposing the trees in the transition zone to substantially drier springtime conditions that limit soil moisture and reduce radial growth. Although the most severe and persistent droughts were concentrated in the northwest region, four large-scale droughts also impacted the entire interior PNW during the study period. These droughts occurred principally during PDO warm phases, suggesting a regional-scale linkage to this climatic oscillation.
\end{abstract}

\section{Introduction}

On an annual basis, at least one region of the United States is likely to be affected by drought [American Meteorological Society Council (AMSC) 1997]. These droughts vary in their intensity, longevity, and spatial coverage (e.g., Woodhouse and Overpeck 1998; Stahle et al. 2000; Benson et al. 2002; Clarke et al. 2002), with some regions experiencing greater drought frequency and/or persistence (Karl and Koscielny 1982; Soulé 1992; Meko et al. 1993, 1995; Cook et al. 1997, 1999). Drought is unlikely to be singularly caused, but rather reflects a "synergistic interaction" between local-scale surface characteristics (e.g., mountains, snow/ice cover) and regional-scale circulation phenomena [e.g., El Niño-Southern Oscillation (ENSO), Pacific decadal oscillation (PDO), Pacific subtropical high, polar jet

Corresponding author address: Dr. Paul A. Knapp, Department of Anthropology and Geography, Georgia State University, 33 Gilmer Street, University Plaza, Atlanta, GA 30303.

E-mail: gegpak@langate.gsu.edu stream; Namias 1983; AMSC 1997, p. 849; Gershunov et al. 1999; Biondi et al. 2001; Cole et al. 2002]. The specific combination of conditions that promote frequent droughts may vary substantially over short distances given the same regional controls. Further, for those areas that experience more frequent droughts (based on historical records), the question arises whether these patterns remain consistent when extended back through time using proxy climate records, such as treering data.

Historical climate data back to ca. A.D. 1895 and extended back several centuries using tree-ring records have shown that the interior Pacific Northwest (PNW) region commonly experiences persistent droughts (Karl and Koscielny 1982; Trenberth et al. 1988; Soulé 1992; Meko et al. 1993) and is among the more drought-prone regions within the continental United States (Cook et al. 1997). The principal cause for drought in the PNW is generally credited to the development of a blocking high over Vancouver Island (roughly $50^{\circ} \mathrm{N}, 125^{\circ} \mathrm{W}$; Fritts et al. 1979; Namias 1983; Graumlich 1987; 
Hughes and Brown 1992), but little is known about the localized effects of the blocking high on drought frequency and intensity.

In the interior PNW, western juniper (Juniperus occidentalis var. occidentalis Hook.) is a long-lived and climatically sensitive tree that is an excellent species to use for drought reconstructions (Knapp et al. 2002). Particularly advantageous characteristics of this species are exceptionally high ring-width variability coupled with radial growth patterns that are significantly influenced by winter/spring precipitation (Knapp et al. 2001a,b). Western juniper is most common in central Oregon where it is often found on climatically and topoedaphically marginal sites. However, it has a significant geographical range and can be found in northern California, Nevada, southeastern Idaho, and south-central Washington (Bedell et al. 1993). Thus, regional-scale assessments of drought can be examined using a single species.

In this paper we examine the spatial patterns of moderate sustained droughts and "severe sustained droughts" (Meko et al. 1995, p. 789) in the interior PNW using tree-ring data over the period 1733-1980. Our primary objective is to demonstrate that drought frequency, particularly severe droughts, can be substantially impacted by spatial variability of climatic transition zone boundaries. An understanding of severe single-year drought events is vital largely because they are closely associated with regime shifts of synoptic-scale climate controls. For example, drought conditions during and just prior to 1924 and 1976 corresponded with the ending of PDO cold-phase conditions in the PNW (Knapp et al. 2002). Sustained droughts, however, also typically impart significant ecological and economic influences upon a much broader region (Woodhouse and Overpeck 1998; Clarke et al. 2002). Accordingly, we were interested in selecting multiyear sequences of moderate or severe drought conditions that could potentially reveal regions that have been historically more prone to extended droughts. We compare drought frequency between three climatically defined regions (Knapp et al. 2002) and discuss the possible causes for the differences in drought frequency.

A second objective is to determine whether a drought core region exists in the interior Pacific Northwest and if so, examine the mechanisms that promote its occurrence. Core regions for drought have been identified in the western and central United States (e.g., McGregor 1985; Woodhouse et al. 2002). Within these core regions, droughts tend to originate, expand, and then persist even during years of regional contraction (McGregor 1985; Woodhouse et al. 2002).

\section{Methods}

a. Tree-ring data

Our data consisted of 18 western juniper tree-ring chronologies collected from northern California, south- western Idaho, northern Nevada, and central and eastern Oregon (Table 1; Fig. 1). The chronologies represent sites throughout most of the geographical distribution of this species in the interior PNW. Eleven chronologies that were collected in the early 1980s (Holmes et al. 1986) were obtained electronically from the International Tree Ring Data Bank (Grissino-Mayer and Fritts 1997). The remaining seven chronologies were collected in the latter half of the 1990s (Knapp et al. 2001a,b, 2002). All 18 chronologies were cross-dated and measured using standard dendrochronological techniques (Stokes and Smiley 1968), with dating and measurement accuracy statistically checked by the computer program COFECHA (Holmes 1983; Grissino-Mayer 2001). All raw measurement series were conservatively standardized using the negative exponential curve option in the computer program ARSTAN (Cook 1985) to preserve low-frequency (i.e., interannual) variability (Briffa et al. 1996). For our analyses, we selected the standard version of the ARSTAN-generated chronologies because this version best preserves low-frequency trends and its common usage allows for easy interpretation.

Although many of the western juniper chronologies exceeded $500 \mathrm{yr}$ in length and some extend through 1998, a common period across all sites, 1733-1980, was required for regional comparisons. Most drought indices (e.g., the Palmer Drought Severity Index; Palmer 1965) are based on a definition of drought as a deviation from normal climate for a given region. Because annual treering indices (ATRI) for a given site are standardized to a mean of 1.00 , we identified drought years based on radial growth being $20 \%$ below average ("moderate drought," ATRI of 0.8 ) and $40 \%$ below average ("severe drought," ATRI of 0.6). For each chronology location we mapped the number of occurrences of multiyear droughts for both the 0.8 and 0.6 threshold. We identified these events as moderate sustained droughts (MSDs) and severe sustained droughts (SSDs) and then plotted the temporal occurrence of both MSD and SSD events by site.

\section{b. Climate data}

Because on-site climatic data are not available at any of the chronology sites, we mapped November-May precipitation (shown as isohyets throughout the interior PNW) to identify approximate precipitation amounts for each chronology. We selected November-May total precipitation because radial growth of western juniper in Oregon is strongly correlated $\left(r^{2}=0.61\right)$ with these months (Grissino-Mayer et al. 2001). For our map, we used monthly precipitation means based on the period 1971-2000 obtained from the National Climatic Data Center (see online at http://www5.ncdc.noaa.gov/ climatenormals/clim81/). Precipitation data from 1030 climate observation stations (all available stations in California, Idaho, Nevada, Oregon, and Washington) were 
TABLE 1. Site details, mean sensitivity, and frequency of MSDs and SSDs for each chronology. Data in bold type represent means for each region.

\begin{tabular}{|c|c|c|c|c|c|c|c|c|}
\hline Site name/region & Site & $\begin{array}{c}\text { Chronology } \\
\text { period }\end{array}$ & $\begin{array}{l}\text { Lat } \\
\left({ }^{\circ} \mathrm{N}\right)\end{array}$ & $\begin{array}{l}\text { Lon } \\
\left({ }^{\circ} \mathrm{W}\right)\end{array}$ & $\begin{array}{l}\text { Elev } \\
(\mathrm{M})\end{array}$ & $\begin{array}{c}\text { Frequency } \\
2+\text { year } \\
\text { events } \\
\text { ATRI < } 0.8 \\
\text { (MSDs) }\end{array}$ & $\begin{array}{l}\text { Frequency } \\
2+\text { years } \\
\text { events } \\
\text { ATRI < } 0.6 \\
\quad(\text { SSDs })\end{array}$ & $\begin{array}{c}\text { Mean } \\
\text { sensitivity }\end{array}$ \\
\hline \multicolumn{9}{|l|}{ Northwest } \\
\hline Sutton Mt. PRNA & STU & 1709-1998 & 44.68 & 120.23 & 800 & 26 & 15 & 0.6 \\
\hline The Island RNA & IRN & 1733-1996 & 44.57 & 121.27 & 730 & 20 & 9 & 0.63 \\
\hline Haystack Butte PNRA & $\mathrm{HBU}$ & 1596-1998 & 44.45 & 121.15 & 1185 & 17 & 11 & 0.67 \\
\hline Powell Butte & PBU & 1665-1998 & 44.15 & 121 & 1220 & 20 & 12 & 0.7 \\
\hline Horse Ridge & HOR & 1281-1982 & 43.97 & 121.07 & 1109 & 15 & 8 & 0.59 \\
\hline Horse Ridge RNA & HRN & 1613-1996 & 43.92 & 121.03 & 1300 & 8 & 6 & 0.5 \\
\hline Frederick Butte & FRE & $1097-82$ & 43.58 & 120.45 & 1433 & 10 & 7 & 0.46 \\
\hline Benjamin RNA & $\mathrm{BNU}$ & 1682-1998 & 43.58 & 120.35 & 1510 & 15 & 5 & 0.38 \\
\hline \multirow[t]{2}{*}{ Little Juniper Mt. } & LIT & 1377-1982 & 43.13 & 119.87 & 1524 & 14 & 5 & 0.43 \\
\hline & & & & Mean $\rightarrow$ & $1201 * *$ & $16.1^{*}$ & $8.7 * *$ & $0.55 * *$ \\
\hline \multicolumn{9}{|l|}{ East } \\
\hline Steens Mt. & STE & 1501-1982 & 42.67 & 118.92 & 1625 & 10 & 0 & 0.25 \\
\hline Grasshopper Trail & GRA & 1396-1982 & 42.22 & 116.8 & 1689 & 13 & 1 & 0.27 \\
\hline Spring Canyon & SPR & 1405-1982 & 44.9 & 118.92 & 1340 & 9 & 1 & 0.29 \\
\hline Jackson Mts. & JAC & 1267-1984 & 41.3 & 116.43 & 2024 & 14 & 3 & 0.27 \\
\hline \multirow[t]{2}{*}{ Calamity Creek } & CAL & 1396-1982 & 43.98 & 118.8 & 1433 & 10 & 0 & 0.27 \\
\hline & & & & Mean $\rightarrow$ & 1622 & 11.2 & 1 & 0.27 \\
\hline \multicolumn{9}{|l|}{ Southwest } \\
\hline Goodlow Mt. RNA & GMU & 1285-1998 & 42.2 & 121.18 & 1555 & 9 & 1 & 0.28 \\
\hline Hager Basin & HAG & 1319-1980 & 41.77 & 120.75 & 1518 & 7 & 0 & 0.23 \\
\hline Sharp Mt. & SHR & 1548-1982 & 41.73 & 121.82 & 1335 & 11 & 4 & 0.31 \\
\hline \multirow[t]{2}{*}{ Timbered Mt. } & TIM & $1654-1980$ & 41.72 & 120.75 & 1555 & 12 & 0 & 0.22 \\
\hline & & & & Mean $\rightarrow$ & 1491 & 9.8 & 1.3 & 0.26 \\
\hline
\end{tabular}

* Significant differences among the three regions at $p<0.05$.

** Significant differences among the three regions at $p<0.01$.

plotted using ArcGIS 8.1 to create a map illustrating isohyets in the interior PNW.

In regionalizing climate in the West, Mitchell (1976) identified a climatic transition zone in the interior PNW oriented southwest to northeast from the east side of the southern Oregon/northern California Cascades to the northwest corner of Montana. This transition zone, approximately $150 \mathrm{~km}$ wide, separated the influence of perennial marine airflow on the western side to a split regime on the eastern side (i.e., marine air influence during the cooler months and interior air dominance during the warmer months). To examine the potential influence of the thermal climate on western juniper growth within this transition zone, we used spring (i.e., average of March, April, and May) temperatures for all climate stations falling within $45^{\circ} \mathrm{N}, 121.5^{\circ} \mathrm{W}$ and $42^{\circ} \mathrm{N}$, $117.5^{\circ} \mathrm{W}(n=52)$. This section of the interior PNW was selected because it represents the region of Mitchell's transition zone that also overlapped the location of the majority $(67 \%)$ of our chronologies. Using a $1^{\circ}$ latitude $\times 1^{\circ}$ longitude grid, we averaged the temperature values from all climatic stations within each of the resulting 12 grid cells. Spring was selected because it represents a transition period from marine to interior air dominance that coincides with a critical growth period for western juniper (Fritts and Wu 1986; Knapp et al. 2001a,b). Our temperature dataset used monthly station normals based on the years 1971-2000 (see online at http://www5.ncdc.noaa.gov/climatenormals/clim81/ ORnorm.txt). To compensate for the influence of elevation and thus allow comparative analyses of temperature throughout the transition zone, temperature data for all stations were standardized to an elevation of 1660 $\mathrm{m}$ [that of Bend, Oregon, a centrally located U.S. Historical Climate Network (USHCN) station] using the standard environmental lapse rate of $6.4^{\circ} \mathrm{C} 1000 \mathrm{~m}^{-1}$.

We next wished to determine whether deviations from normal climatological conditions during the spring transition period during drought years were more pronounced within the Northwest climate region (Knapp et al. 2002; Fig. 1) compared to those sites outside of this region. We examined both monthly spring precipitation totals and monthly spring maximum temperatures for the period 1947-80. Maximum temperatures were chosen because of their potential to enhance evapotranspiration and thus exacerbate drought. We selected all USHCN stations located east of the Cascades Mountains and within the Northwest region $(n=4)$ and those stations $<100 \mathrm{~km}$ but outside of the NW region and transition zone $(n=3)$. Monthly average values between eight selected severe drought years (1947, 1955, $1959,1973,1975,1976,1977)$ and the remaining years 


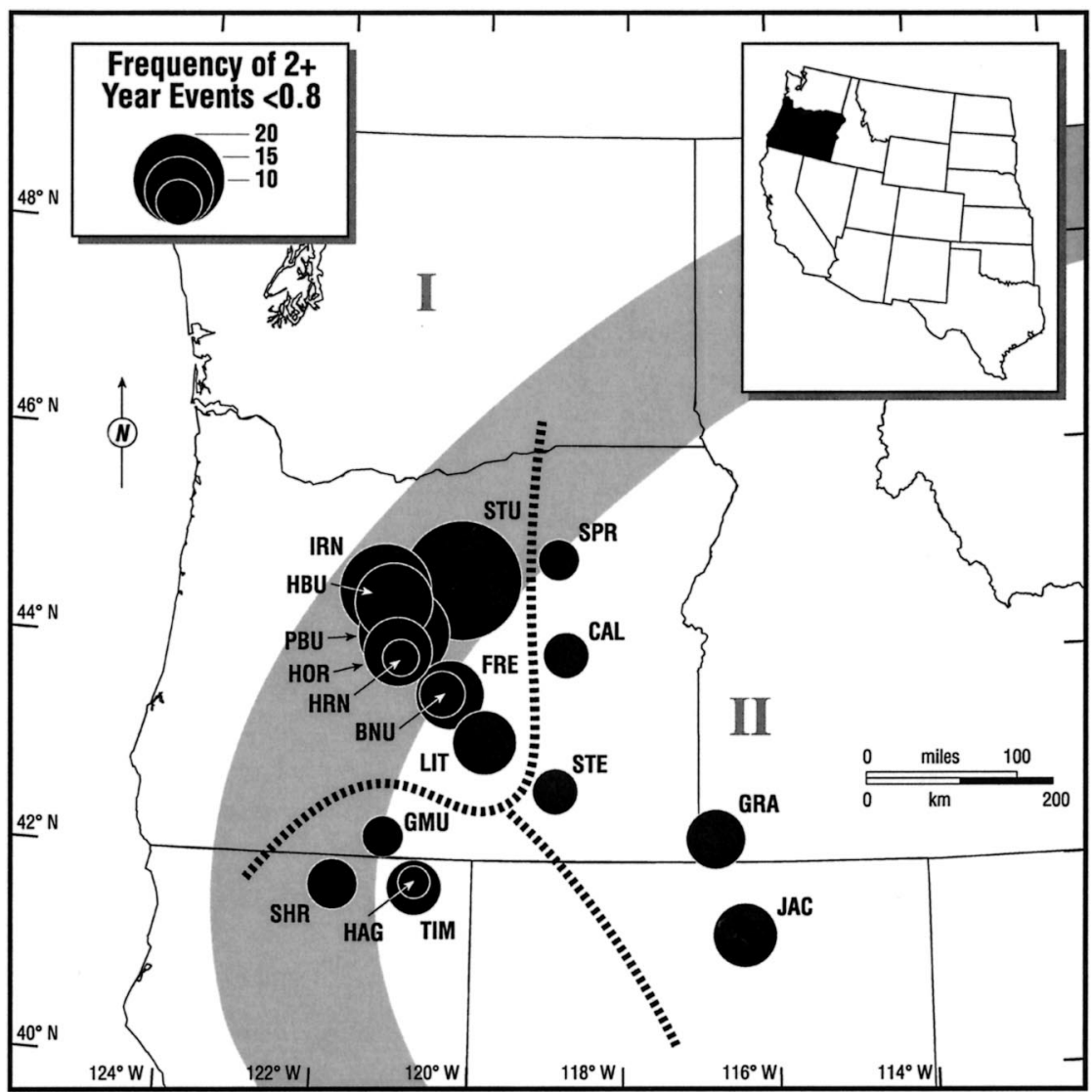

FIG. 1. Frequency of MSDs in the interior PNW during 1733-1980. Size of circle indicates number of MSDs. Dashed line represents the location of climatic boundaries (i.e., Northwest, East, Southwest) identified by Knapp et al. (2002). The shaded area is the transition zone determined by Mitchell (1976) separating Mitchell's defined region "I" (marine air influence yearround) and region "II" (marine air dominance in winter, interior air dominance in summer).

( $n=26)$ were then compared between the two groups of stations using $t$ tests. The severe drought years were chosen because they had ATRI values $<0.6$ from a site (HBU; see Table 1) with exceptional sensitivity to climate, a strong correlation between radial growth and winter/spring precipitation, and a high percentage of trees older than 400 yr. Thus, we believe this chronology is an ideal proxy for examining years of exceptional drought.

\section{c. $700-h P a$ data}

We examined 700-hPa height data (Namias 1979; more information online at http://dss.ucar.edu/datasets/ ds085.1) from the beginning of geopotential height data (1947) to the end of our tree-ring data (1980) to reveal height anomalies and thus upper-level airflow during years of severe drought. Based on a $5^{\circ} \times 5^{\circ}$ grid from $40^{\circ} \mathrm{N}, 110^{\circ} \mathrm{W}$ to $55^{\circ} \mathrm{N}, 145^{\circ} \mathrm{W}$, we calculated mean spring $700-\mathrm{hPa}$ heights. We then calculated the mean 700-hPa height anomalies for the eight selected severe drought years for each grid point. These anomalies rep- resent the difference in $700-\mathrm{hPa}$ height of these eight years compared to the mean 700-hPa height of the 194780 period excluding the severe drought years.

\section{d. Comparison of means}

We used the regional breakdown of sites identified by Knapp et al. (2002) to determine whether significant spatial differences exist in the frequency of MSDs, SSDs, elevation, and mean sensitivity of the standardized tree-ring indexes. We used the Kruskal-Wallis test (McGrew and Monroe 2000) with a null hypothesis that states no significant difference exists (with $\alpha$ set at 0.05) among the Northwest $(n=9)$, East $(n=5)$, and Southwest $(n=4)$ regions.

\section{e. Determination of ENSO mode and PDO phase during regionally widespread drought sequences}

We identified regionally widespread droughts as those where at least two-thirds of the sites (i.e., 12) were experiencing a SMD. When at least half (i.e., 9) of the 


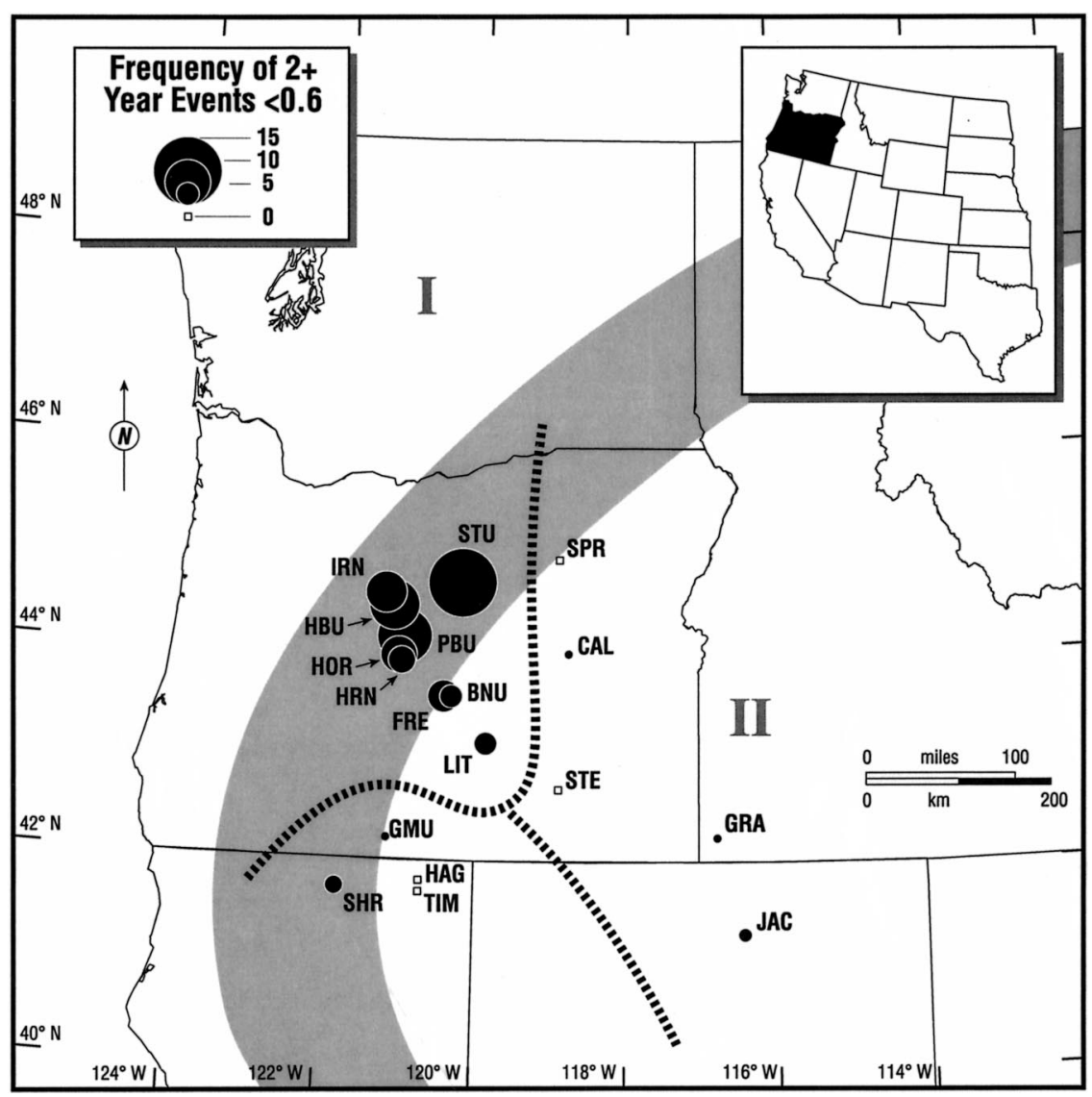

FIG. 2. Same as Fig. 1 but for SSDs.

sites were experiencing a SMD, the drought sequence was extended beyond two years We then compared regionally widespread drought sequences to the ENSO mode and PDO phase. The ENSO mode was identified as either El Niño (EN), neutral (N), or La Niña (LN) based on dendroclimatic reconstructions by Stahle et al. (1998). We identified the PDO phase as identified as warm (W), N, or cold (C) based on dendroclimatic reconstructions by Gedalof and Smith (2001).

\section{Results}

\section{a. Frequency of MSD and SSD events}

We found significant regional variation in the frequency of MSDs $(p \leq 0.05)$ and $\operatorname{SSDs}(p \leq 0.002)$ (Table 1; Figs. 1 and 2). The spatial patterning between regions, however, was most pronounced for SSDs (Fig. $2)$. Noteworthy are the number of sites $(n=7)$ that experienced less than two SSDs and that no site in the East or Southwest region had greater than four SSDs during the 1733-1980 period. In addition, we found significant differences in elevation $(p \leq 0.02)$ and mean sensitivity ( $p \leq 0.002$ ) (Table 1$)$. Among all sites, the most notable aspects of the temporal occurrence of both MSDs and SSDs are the duration of the 1930s drought and the relative gaps that exist in SSDs before and after the high frequency years of the 1930s (Figs. 3 and 4).

Substantial differences also exist in the median dates for drought onset and cessation and the mean drought lengths between the three regions. For example, the median onset of the 1930s drought, the longest for the entire study period (Figs. 3 and 4), began in the Northwest region a full two to three years earlier than the Southwest and East regions, respectively (Table 2) when using MSD criteria (i.e., minimum two consecutive years with a growth index $<0.8$ ). The median ending date for the 1930s drought was two years earlier in the Southwest and East regions compared to the Northwest region. When using SSD criteria (i.e., minimum two consecutive years with a growth index $<0.6)$, the relationship is less clear for the median onset and cessation dates as approximately half the sites in the Southwest and East regions did not experience SSDs (Table 2). Conversely, the mean drought length remains substantially different between the Northwest region and the two other regions.

\section{b. 700-hPa anomalies}

Geopotential height data anomalies for spring support the observation that, during years of low ATRI values 


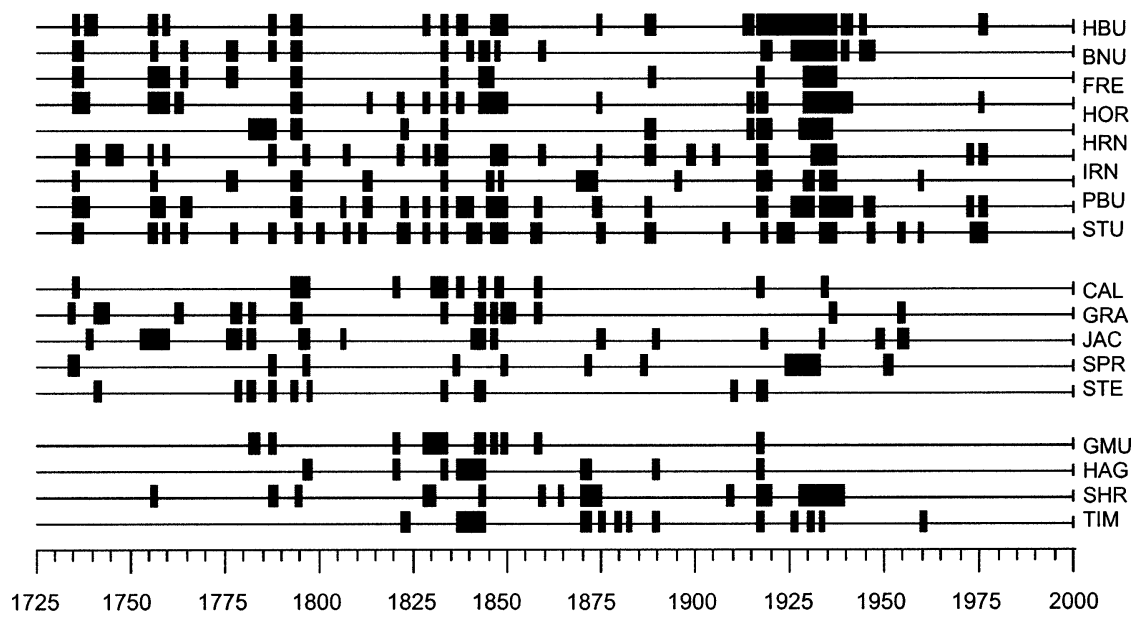

FIG. 3. Temporal occurrence of MSDs for each of the 18 chronologies.

(i.e., the eight selected dry years), a strong ridge forms off the West Coast with significant anomalies between $35^{\circ}-45^{\circ} \mathrm{N}$ and $130^{\circ}-145^{\circ} \mathrm{W}$ (height anomalies range from approximately 15 to $20 \mathrm{~m}$; Table 3; Fig. 5). Increasingly negative (but nonsignificant) anomalies begin occurring east of $120^{\circ} \mathrm{W}$ (Table 3; Fig. 5). These data show the presence of a blocking high that would reduce the frequency of midlatitude cyclones and the onshore flow of marine air toward the interior Pacific Northwest. While the blocking high is present over Vancouver Island (roughly $50^{\circ} \mathrm{N}, 125^{\circ} \mathrm{W}$ ), a finding presented by others as the primary synoptic-scale cause of drought in the PNW (e.g., Fritts et al. 1979; Namias 1983; Graumlich 1987; Hughes and Brown 1992), we note that the ridge is most strongly developed well to the south and west (i.e, closer to $35^{\circ}-40^{\circ} \mathrm{N}$ and $135^{\circ}-140^{\circ} \mathrm{W}$ ).

\section{c. Climate data}

Spring temperature patterns within the transition zone correspond closely to Mitchell's analysis with two standout features (Table 4). First, there is a strong latitudinal gradient in temperature. The mean spring temperature for all sites between $44^{\circ}$ and $45^{\circ} \mathrm{N}$ was $1.3^{\circ} \mathrm{C}$ cooler than the mean of all sites from $42^{\circ}$ to $43^{\circ} \mathrm{N}$. Second, latitudinal changes in temperature are strongly influenced by longitude (i.e., the rate in which temperatures change from north to south increases from west to east). For example, mean spring temperatures in the northwest grid $\left(44^{\circ}-45^{\circ} \mathrm{N}, 120.5^{\circ}-121.5^{\circ} \mathrm{W}\right)$ were $0.1^{\circ} \mathrm{C}$ cooler than those in the southwest grid $\left(42^{\circ}-43^{\circ} \mathrm{N}\right.$, $\left.120.5^{\circ}-121.5^{\circ} \mathrm{W}\right)$. Conversely, the mean spring temperature from the northeast to southeast grids $\left(44^{\circ}-45^{\circ} \mathrm{N}\right.$, $117.5^{\circ}-118.5^{\circ} \mathrm{W}$ to $\left.42^{\circ}-43^{\circ} \mathrm{N}, 117.5^{\circ}-118.5^{\circ} \mathrm{W}\right)$ differed by $2.9^{\circ} \mathrm{C}$. Thus, these results suggest that the moderating influence of marine air in the interior PNW extends farther east at higher latitudes, as would be expected by Mitchell's (1976) transition boundary.

Springtime precipitation totals during the eight selected dry years are significantly less within the Northwest region than those stations adjacent to the region (Table 5). Conversely, comparisons of springtime tem-

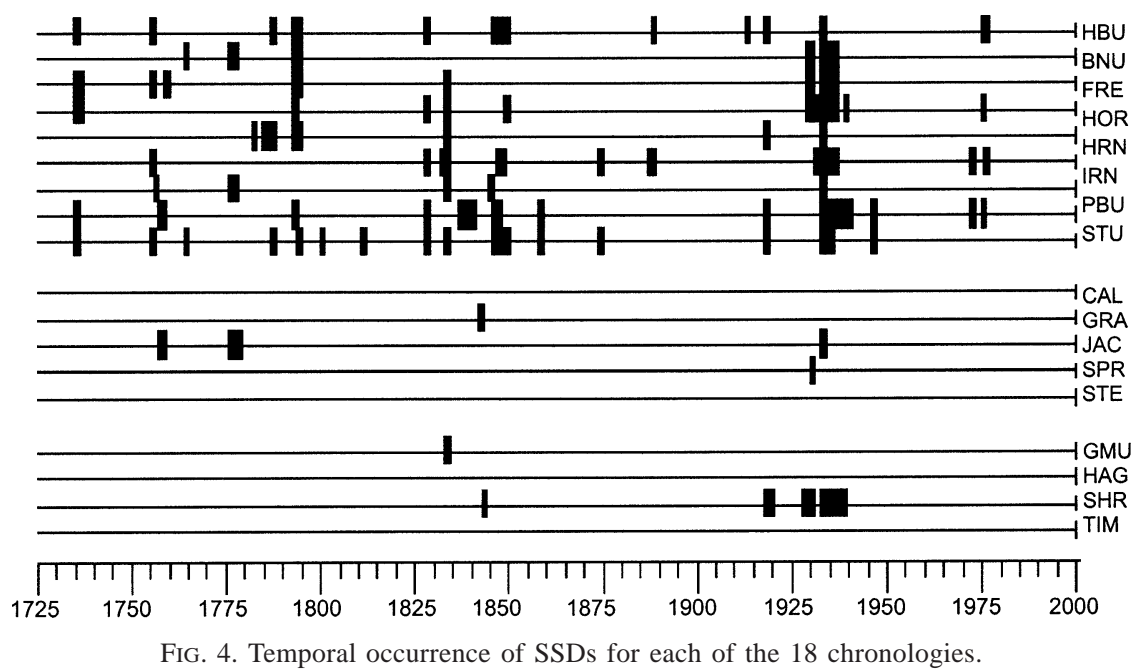


TABLE 2. Duration of sustained droughts (i.e., minimum two consecutive years) based on 1930s drought period. Median beginning and ending periods for droughts are shown in bold for both moderate (index $<0.8$ ) and severe (index $<0.6$ ) criteria. Mean drought lengths (no. of consecutive years/no. chronologies) are shown parenthetically. Sites that did not experience sustained droughts are marked with NA.

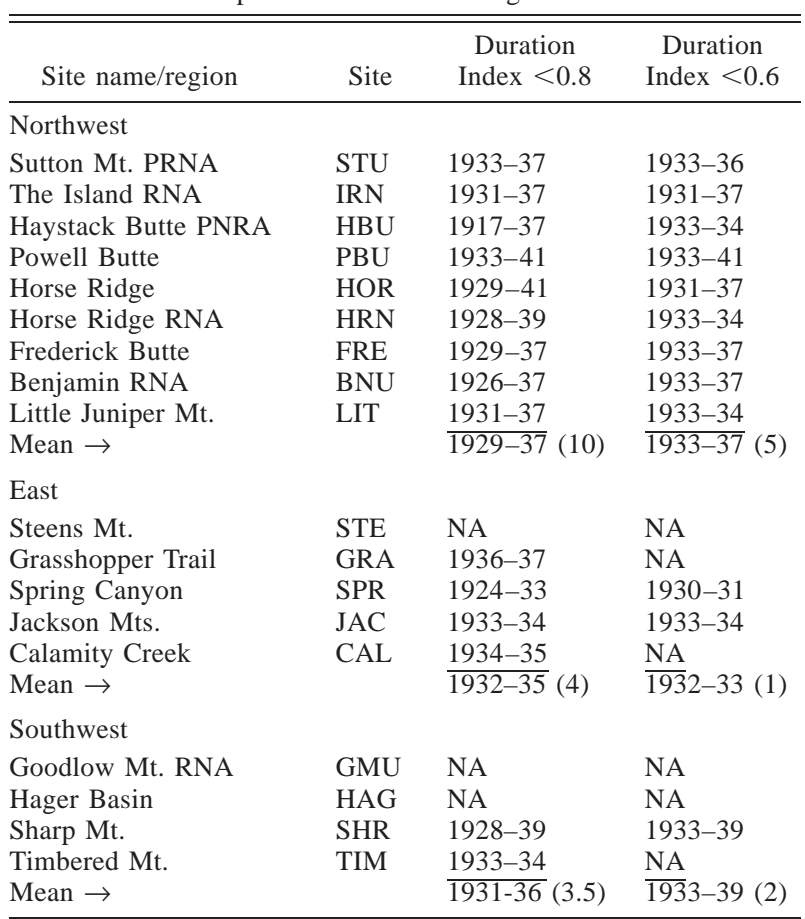

perature between the eight dry years and the 26 nondry years showed no significant differences (Table 5).

\section{d. PDO-ENSO relationships}

There were four periods of MSDs between 1733 and 1980 that were characterized by their large-scale distribution (Table 6; Fig. 3). Three of the four droughts occurred during a PDO warm phase, while the 191719 event occurred when the PDO was weak and in a neutral phase (Gedalof and Smith 2001; our Table 6). No widespread droughts occurred during a PDO cold phase. These droughts were not consistently associated

TABLE 3. Spring 700-hPa height data anomalies $(\mathrm{m})$ for severe drought years $(n=8)$ compared to all other years $(n=26)$ by $5^{\circ} \times$ $5^{\circ}$ grid coordinates. Numbers in bold indicate significance $(p<0.05)$ between severe drought and other years (two-tailed $t$ test, unequal variance). Italicized numbers are interpolated based on surrounding actual data.

\begin{tabular}{crrrrrrrr}
\hline \hline \multirow{2}{*}{$\begin{array}{c}\text { Lat } \\
\left({ }^{\circ} \mathrm{N}\right)\end{array}$} & 145 & 140 & 135 & 130 & 125 & 120 & 115 & 110 \\
\cline { 2 - 9 } & \multicolumn{10}{c}{ Lon $\left({ }^{\circ} \mathrm{W}\right)$} \\
\hline 55 & -11 & -8 & -4 & -2 & 0 & -1 & -2 & \\
50 & -1 & 3 & 6 & 6 & 5 & 0 & -2 & -0.3 \\
45 & 9 & 12 & $\mathbf{1 6}$ & 12 & 1 & 2 & -1 & -4 \\
40 & 16 & $\mathbf{2 1}$ & 18 & $\mathbf{1 7}$ & 9 & 4 & -2 & -4 \\
35 & $\mathbf{2 3}$ & 22 & $\mathbf{2 0}$ & 14 & 8 & 2 & -4 & \\
\hline
\end{tabular}

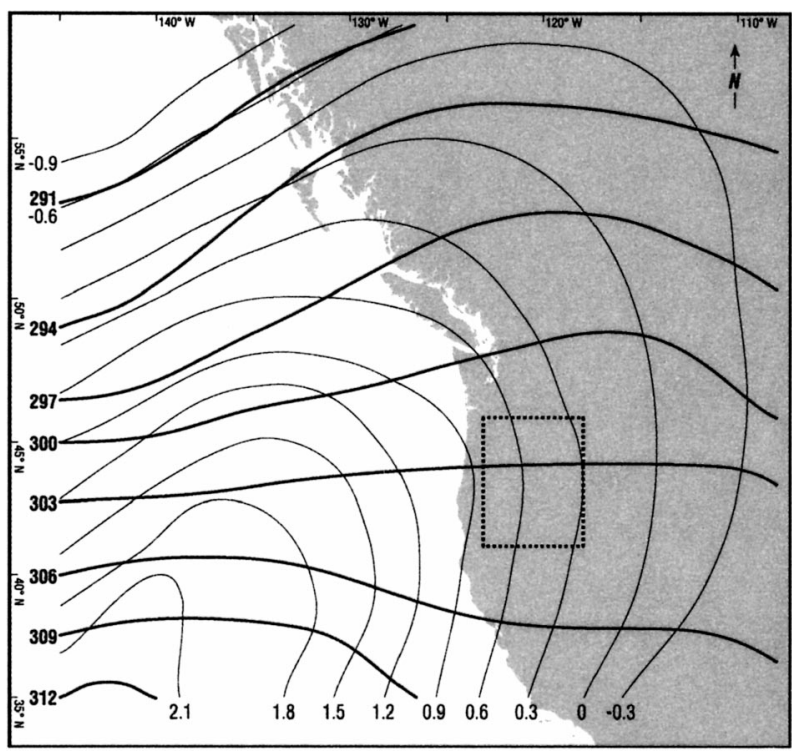

FIG. 5. Mean 700-hPa heights (bold lines, tens of meters) for spring for period 1947-80 excluding eight severe drought years. Thin lines indicate height anomalies (tens of meters) based on mean of the eight severe drought years. Approximate boundaries of the study area are outlined by a dashed pattern.

with a specific ENSO mode (Stahle et al. 1998; our Table $6)$.

\section{Discussion}

Regardless of drought intensity, drought frequency is significantly greater in the Northwest region of the interior PNW. The driving forces for this are likely complex, but we believe that the intra-annual variability of maritime/interior airmass dominance within the Northwest region is a primary factor. For most years, the Northwest chronologies lie within the moderating influence of this transition zone and thus benefit from the cool, wet conditions in winter and spring. Because these conditions promote western juniper growth (Fritts and Wu 1986), the reduction or absence of marine air would limit radial growth. Furthermore, because of the southwest to northeast orientation of this marine/interior boundary, we suggest that tree growth in the Northwest region would be more strongly impacted by deviations from mean conditions compared to the East or Southwest regions. The patterns of both MSDs and SSDs

TABLE 4. Mean spring temperature $\left({ }^{\circ} \mathrm{C}\right)$ for $1^{\circ} \times 1^{\circ}$ grids in Oregon, based on averages from 1971 to 2000 . Numbers shown parenthetically represent number of stations used for averages.

\begin{tabular}{ccccc}
\hline \hline \multirow{2}{*}{$\begin{array}{c}\text { Latitudinal } \\
\text { range }\left({ }^{\circ} \mathrm{N}\right)\end{array}$} & \multicolumn{5}{c}{ Longitudinal range $\left({ }^{\circ} \mathrm{W}\right)$} \\
\hline $44-45$ & $15.4(10)$ & $14.7(4)$ & $14.4(4)$ & $14.2(4)$ \\
$44-43$ & $14.6(4)$ & $14.4(4)$ & $15.1(3)$ & $17.0(5)$ \\
$43-42$ & $15.3(4)$ & $14.8(5)$ & $16.6(1)$ & $17.1(4)$ \\
\hline
\end{tabular}


TABLE 5. Monthly precipitation (percentage of normal) and temperature deviations (from mean maximum in ${ }^{\circ} \mathrm{C}$ ) for eight severe drought years compared to remaining years based on period of record 1947-80. USCHN stations were either in the NW region or within $100 \mathrm{~km}$ of the NW region boundary. Significance between dry years and all other years based on two-tailed $t$ test with unequal variance.

\begin{tabular}{lcccr}
\hline \hline \multirow{2}{*}{ Region } & \multicolumn{5}{c}{ Month } \\
\cline { 2 - 5 } Mar & Apr & May & Avg \\
\hline NW & \multicolumn{5}{c}{ Precipitation } \\
Adjacent NW & $58^{* *}$ & 80 & $65^{* *}$ & $65^{* *}$ \\
& & 77 & $76^{*}$ & $74^{* *}$ \\
NW & & Temperature & & \\
Adjacent NW & -0.5 & 0.9 & 0.1 & 0.2 \\
\hline
\end{tabular}

$* p<0.05$.

$* * p<0.01$.

(Figs. 1 and 2) show an abrupt transition in frequency in eastern Oregon. With the exception of site LIT, no chronology outside of the transition boundary experienced a greater frequency of SSDs than any chronology within the boundary.

Geopotential height anomaly data support our argument that those years with low tree-ring index values correspond with the springtime presence of a ridge of high pressure off the West Coast (Table 3; Fig. 5). The presence of this ridge does not affect the climatic conditions of the interior Pacific Northwest equally, but rather causes greater deviations from average conditions in the Northwest region (Table 5) for two reasons. First, substantial differences exist in the timing of seasonal precipitation maxima in the interior PNW (Mock 1996). In general, the climatic boundary (Figs. 1 and 2) separating the NW region from the other two regions represents a divide between precipitation maxima in winter (November-December for the NW region, JanuaryFebruary for the SW region) and late spring (May-June for the East region; Mock 1996). A blocking high would steer midlatitude cyclones away from the interior PNW during the cooler months, causing drier conditions to prevail. The impact of this reduction would be proportionally greater for those areas more dependent on cool season precipitation (Table 5). Second, the geopotential height anomaly is greater on the western edge of the interior PNW (i.e., the NW region), and the drying ef- fects of atmospheric subsidence should more directly affect this region.

Elevation may further exaggerate the spatial patterning of MSDs and SSDs. The Northwest chronologies were developed from trees sampled at significantly lower elevation than trees sampled in the East and Southwest regions (Table 1). While elevation is not integrated in indices of tree growth, trees collected at lower elevations in the PNW should have greater variability in their ATRIs primarily because they experience higher rates of evapotranspiration as a result of comparatively higher temperatures during the growing season. This relationship is reflected in the mean sensitivity of the chronologies, with the Northwest region sites averaging greater than twice the mean sensitivity than any chronology in either the East or Southwest regions (Table 1). In addition, while there are only minor differences in November-May precipitation totals throughout the interior PNW (Fig. 6), substantial differences occur in the timing of precipitation maxima (i.e., winter versus spring) that impact the phenology of tree growth. Finally, Ferguson (1999, p. 8) has noted that Arctic air that flows into the Columbia basin can retrograde to the base of the eastern Cascades causing a "persistent temperature inversion to about $1200 \mathrm{~m}$." This phenomenon also could account for the high variability in mean sensitivity for those sites closest to the Cascades. Given that western juniper prefer warm, wet winters (Fritts and $\mathrm{Wu}$ 1986), cold-season temperature inversions should negatively impact radial growth.

Regional-scale MSDs in the interior PNW are more likely to occur during either a warm or neutral phase of the PDO, but are not supported during a PDO cold phase. While sustained droughts are not absent during cold PDO phases, they are geographically isolated. Our findings are in general agreement with Mantua et al. (1997), Pohl et al. (2002), and Benson et al. (2003) who all found that drier conditions prevailed during PDO warm phases for locations northward of approximately $38^{\circ} \mathrm{N}$. Conversely, for our 18 selected sites, the ENSO mode does not appear to have a significant influence on drought occurrence, as no mode was dominant during the different drought intervals. While this finding is in general agreement with other studies from the interior Pacific Northwest (e.g., Keen 1937; Pohl et al. 2002), it is different both in that persistent droughts in the

TABLE 6. Relationship between ENSO mode and PDO phase during regionally widespread droughts. Number of chronologies refers to the number of study sites where there were at least two consecutive years of MSDs. ENSO mode symbols: EN = El Niño, $\mathrm{N}=$ neutral and $\mathrm{LN}=$ La Niña. PDO phase symbols: $\mathrm{W}=$ warm and $\mathrm{N}=$ neutral.

\begin{tabular}{lcll}
\hline \hline \multicolumn{1}{c}{ Years } & No. of chronologies & ENSO mode* \\
\hline $1793 / 1794 / 1795$ & $9,12,12$ & EN, N, N & PDO phase** W, W, W \\
$1833 / 1834$ & 14,14 & EN, N & W, W \\
$1917 / 1918 / 1919$ & $13,16,11$ & N, LN, N, N, N \\
$1933 / 1934 / 1935 / 1936 / 1937$ & $13,13,11,11,10$ & N, N, N \\
\hline
\end{tabular}

* Source: Stahle et al. (1998).

** Source: Gedalof and Smith (2001). 


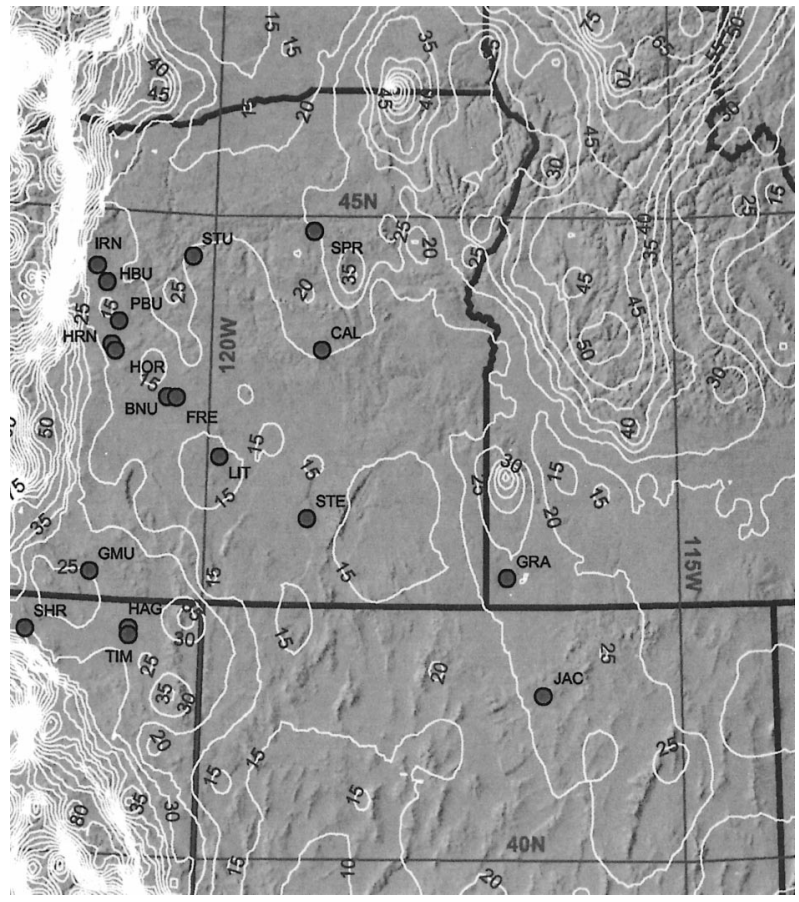

FIG. 6. Nov-May precipitation $(\mathrm{cm})$ for interior PNW sites. Isohyets at 5-cm intervals. (Data source: http://www5.ncdc.noaa.gov/ climatenormals/clim81/.)

southwestern United States are consistently influenced by La Niña events and that these events can be intensified when occurring during cold PDO phases (Cole et al. 2002). Thus, a substantial difference may exist between the large-scale circulation features that may either cause or intensify persistent, large-scale droughts in the American West. In the interior PNW, the PDO phase has a greater influence than the ENSO mode. In the Southwest, however, La Niña is often the primary cause of droughts and a cold PDO phase tends to reinforce existing La Niñas (Cole et al. 2002).

Several other factors may impact drought frequency, including soil type, slope, aspect, and site selection factors. The influence of soil type is intriguing, as equivalent amounts of precipitation support different tree species in the interior PNW. For example, within the core range of western juniper (i.e., central Oregon east of the Cascades), sandy soils (typically derived from eolian pumice from Mt. Mazama eruptions) can support climatically disjunct stands of ponderosa pine (Pinus ponderosa Dougl ex. Laws.). The Lost Forest stand of ponderosa pine growing in the deep, sandy soils of eastern Oregon (Moir et al. 1972) occurs within a climate that would be too arid to support this species in the absence of the unusual edaphic conditions. The Northwest region chronologies $(n=9)$ all are located within three ecological provinces of Oregon (Mazama, John Day, and High Desert) that because of great similarities in climate are largely defined based on topoedaphic differences (Anderson et al. 1998). Further, many of the trees se- lected for chronology development were the oldest onsite, and these often were located on fire-resistant rock outcrops with poorly developed soils. While it is tempting to ascribe differences in drought frequency to the influence of soils, we note that three chronologies with low drought frequencies (CAL, SPR, and STE) also occur within these provinces. Thus, despite similarities in topoedaphic characteristics, substantial differences exist in drought frequency.

\section{Conclusions}

The spatial patterns of drought frequency and duration we have presented suggest the presence of a core region for drought (i.e., a drought zone) in the interior Pacific NW. Similar to core regions in the Great Plains (e.g., McGregor 1985; Woodhouse et al. 2002), understanding the locations of these drought zones is important because they may be the first areas to experience the effects of a sustained drought that can affect a much larger region (Woodhouse et al. 2002). Further, the relative longevity of tree-ring data allows the placement of drought frequency and duration in a historical context that in turn could help in planning for human population growth. As the NW region largely covers a rapidly growing area of Oregon, the need for water and the potential impact of drought-induced shortages may become of paramount importance.

The meaning and impact of drought ("insufficient water to meet needs") can vary substantially over small spatial scales (Redmond 2002, p. 1144). Accordingly, we have shown that a distinct spatial patterning of drought frequency is well expressed in the interior PNW and that the transition from a drought-prone zone (i.e., the NW region) to adjacent, but considerably less drought-frequent, regions can be abrupt. Although we cannot state with certainty the exact mechanisms causing the high frequency of SSDs in the NW region, the close approximation to Mitchell's transition zone suggests that intra-annual variability in maritime versus interior airmass dominance related to enhanced ridging aloft is a principal driving force. In those instances where droughts are regionally distributed, the influence of the PDO may be operative as well.

The examination of the frequency of MSDs and SSDs in the interior PNW further illustrates that the spatial scale in which droughts are assessed is also dependent on drought severity. The boundary separating the Northwest and East regions splits the central Oregon Climatic Division, for example, and different drought frequency regimes exist on either side when examining severe droughts, but largely disappear when examining moderate droughts. Thus, our understanding of both drought frequency and tree growth anomalies (e.g., Brubaker 1980) for the interior PNW can be greatly impacted by the location of the data selected and criteria for drought used. Finally, these findings suggest that chronologies developed from sites within climatic transition zones 
may be desirable when examining spatio-temporal variability of climatic regimes (e.g., Woodhouse and Kay 1990) because of the exceptional sensitivity to dry periods.

Acknowledgments. This study was funded by the U.S. Department of Interior, Bureau of Land Management Challenge Cost Share Grant 1422H050P97004, the National Science Foundation Grant SBR-9809245, and by an Appalachian State University Research Council Grant. We thank Ron Halvorson for providing information on the natural history of the study sites; and Harry Blount, Stacy Carnine, Joel Davis, Betsy Herrmann, Kimberly Eldridge, Alison Miller, Paul Mitchell, Andrew Paul, and Mark Pelfrey for field and/or lab assistance. We also thank Will Fontanez of the University of Tennessee Cartographic Services Laboratory for production of Figs. 1, 2, and 5; and Elaine Hallisey Hendrix of Georgia State University for production of Fig. 6. The constructively critical comments and suggestions of two anonymous reviewers were greatly appreciated.

\section{REFERENCES}

American Meteorological Society Council, 1997: Policy statement on meteorological drought. Bull. Amer. Meteor. Soc., 78, 847-849.

Anderson, E. W., M. M. Borman, and W. C. Krueger, 1998: The Ecological Provinces of Oregon. Oregon Agricultural Experiment Station, $138 \mathrm{pp}$.

Bedell, T. E., L. E. Eddleman, T. Deboodt, and C. C. Jacks, 1993: Western juniper: Its impact and management on Oregon rangelands. Oregon State University Extension Service EC 1417, Corvallis, OR, $15 \mathrm{pp}$.

Benson, L., and Coauthors, 2002: Holocene multidecadal and multicentennial droughts affecting northern California and Nevada. Quat. Sci. Rev., 21, 659-682.

— B. Linsley, J. Smoot, S. Mensing, S. Lund, S. Stine, and A. Sarna-Wojcicki, 2003: Influence of the Pacific decadal oscillation on the climate of the Sierra Nevada, California and Nevada. Quat. Res., 59, 151-159.

Biondi, F., A. Gershunov, and D. R. Cayan, 2001: North Pacific decadal climate variability since 1661 . J. Climate, 14, 5-10.

Briffa, K. R., P. D. Jones, F. H. Schweingruber, W. Karlen, and S. G. Shiyatov, 1996: Tree-ring variables as proxy-indicators: Problems with low-frequency signals. Climatic Variations and Forcing Mechanisms of the Last 2000 Years, P. D. Jones, R. S. Bradley, and J. Jouzel, Eds., NATO ASI Series I, Vol. 41, Springer, 62-74.

Brubaker, L. B., 1980: Spatial patterns of tree-growth anomalies in the Pacific Northwest. Ecology, 61, 798-807.

Clarke, J. S., E. C. Grimm, J. J. Donovan, S. C. Fritz, D. R. Engstrom, and J. E. Almendinger, 2002: Drought cycles and landscape responses to past aridity on prairies of the northern Great Plains, USA. Ecology, 83, 595-601.

Cole, J. E., J. T. Overpeck, and E. R. Cook, 2002: Multiyear La Niña events and persistent drought in the contiguous United States. Geophys. Res. Lett., 29, 1647, doi:10.1029/2001GL013561.

Cook, E. R., 1985: A time series analysis approach to tree ring standardization. Ph.D. dissertation, The University of Arizona, 171 pp.

_ D. M. Meko, and C. W. Stockton, 1997: A new assessment of possible solar lunar forcing of bidecadal drought rhythm in the western United States. J. Climate, 10, 1343-1356.

,$- \ldots$, D. W. Stahle, and M. K. Cleaveland, 1999: Drought reconstructions for the continental United States. J. Climate, 12, $1145-1162$.

Ferguson, S. A., 1999: Climatology of the interior Columbia River Basin. USDA Forest Service PNW-GTR-445, $31 \mathrm{pp}$.

Fritts, H. C., and X. Wu, 1986: A comparison between responsefunction analyses and other regression techniques. Tree-Ring Bull., 46, 31-46.

- G. R. Lofgren, and G. A. Gordon, 1979: Variations in climate since 1602 as reconstructed from tree rings. Quat. Res., 12, 1846.

Gedalof, Z., and D. J. Smith, 2001: Interdecadal climate variability and regime-scale shifts in Pacific North America. Geophys. Res. Lett., 28, 1515-1518.

Gershunov, A., T. P. Barnett, and D. R. Cayan, 1999: North Pacific interdecadal oscillation seen as factor in ENSO-related North American climate anomalies. Eos, Trans. Amer. Geophys. Union, 80, 25-30.

Graumlich, L. J., 1987: Precipitation variation in the Pacific Northwest (1675-1975) as reconstructed from tree-rings. Ann. Assoc. Amer. Geogr., 77, 19-29.

Grissino-Mayer, H. D., 2001: Assessing crossdating accuracy: A manual and tutorial for the computer program COFECHA. Tree-Ring Res., 57, 205-221.

—_, and H. C. Fritts, 1997: The international tree-ring data bank: An enhanced global database serving the global scientific community. Holocene, 7, 235-238.

_- P. T. Soulé, and P. A. Knapp, 2001: A 700-year reconstruction of winter/spring precipitation for south-central Oregon from western juniper (Juniperus occidentalis Hook.) tree rings. Tree Rings and People: An International Conference on the Future of Dendrochronology, M. Kaennel-Dobbertin and O. U. Braeker, Eds., Swiss Federal Research Institute, pg. 95.

Holmes, R. L., 1983: Computer-assisted quality control in tree-ring dating and measurement. Tree-Ring Bull., 43, 69-78.

—_, R. K. Adams, and H. C. Fritts, 1986: Tree-Ring Chronologies of Western North America: California, Eastern Oregon and Northern Great Basin. Chronology Series, Vol. 6. University of Arizona, $182 \mathrm{pp}$.

Hughes, M. K., and P. M. Brown, 1992: Drought frequency in central California since 101 B. C. recorded in giant sequoia tree rings. Climate Dyn., 6, 161-167.

Karl, T. R., and A. J. Koscielny, 1982: Drought in the United States: 1895-1981. J. Climatol., 2, 313-329.

Keen, F. P., 1937: Climatic cycles in eastern Oregon indicated by tree-rings. Mon. Wea. Rev., 65, 175-188.

Knapp, P. A., P. T. Soulé, and H. D. Grissino-Mayer, 2001a: Postdrought growth responses of western juniper (Juniperus occidentalis var. occidentalis) in central Oregon. Geophys. Res. Lett., 28, 2657-2660.

,$- \ldots$, and,$- 2001 \mathrm{~b}$ : Detecting potential regional effects of increased atmospheric $\mathrm{CO}_{2}$ on growth rates of western juniper. Global Change Biol., 7, 903-917.

— , H. D. Grissino-Mayer, and P. T. Soulé, 2002: Climatic regionalization and the spatio-temporal occurrence of extreme singleyear drought events (100-1998) in the interior Pacific Northwest, USA. Quat. Res., 58, 226-233.

Mantua, N. J., S. R. Hare, Y. Zhang, J. M. Wallace, and R. C. Francis, 1997: A Pacific interdecadal climate oscillation with impacts on salmon production. Bull. Amer. Meteor. Soc., 78, 1069-1079.

McGregor, K. M., 1985: Drought during the 1930s and 1950s in the central United States. Phys. Geogr., 6, 188-201.

McGrew, J. C., and C. B. Monroe, 2000: An Introduction to Statistical Problem Solving in Geography. Wm. C. Brown Publishers, 254 pp.

Meko, D. M., E. R. Cook, D. W. Stahle, C. W. Stockton, and M. K. Hughes, 1993: Spatial patterns of tree-growth anomalies in the United States and southeastern Canada. J. Climate, 6, 17731786.

- C. W. Stockton, and W. R. Boggess, 1995: The tree-ring record of severe sustained drought. Water Res. Bull., 31, 789-801. 
Mitchell, V. C., 1976: The regionalization of climate in the western United States. J. Appl. Meteor., 15, 920-927.

Mock, C. J., 1996: Climatic controls and spatial variations of precipitation in the western United States. J. Climate, 9, 1111-1125.

Moir, W. H., J. F. Franklin, and C. Maser, 1972: Lost forest research natural area. Federal Research Natural Areas in Oregon and Washington: A Guidebook for Scientists and Educators, J. F. Franklin, et al., Eds., Suppl. 3, USDA Forest Service, PNW Forest and Range Experiment Station, LT1-LTA.

Namias, J., 1979: Northern Hemisphere Seasonal $700 \mathrm{mb}$ Height and Anomaly Charts, 1947-1978, and Associated North Pacific Sea Surface Temperature Anomalies. CalCOFI Atlas No. 27, Marine Life Research Program, Scripps Institution of Oceanography, 275 pp.

_- 1983: Some causes of United States drought. J. Appl. Meteor., 22, 30-39.

Palmer, W. C., 1965: Meteorological drought. U.S. Weather Bureau Research Paper 45, $58 \mathrm{pp}$

Pohl, K. A., K. S. Hadley, and K. B. Arabas, 2002: A 545-year drought reconstruction for central Oregon. Phys. Geogr., 23, 302-320.

Redmond, K. T., 2002: The depiction of drought. Bull. Amer. Meteor. Soc., 83, 1143-1147.
Soulé, P. T., 1992: Spatial patterns of drought frequency and duration in the contiguous USA based on multiple drought event definitions. Int. J. Climatol., 12, 11-24.

Stahle, D. W., and Coauthors, 1998: Experimental dendroclimatic reconstruction of the Southern Oscillation. Bull. Amer. Meteor Soc., 79, 2137-2152.

- E. R. Cook, M. K. Cleaveland, M. D. Therrell, D. M. Meko, H. D. Grissino-Mayer, E. Watson, and B. H. Luckman, 2000: Tree-ring data document 16 th century megadrought over North America. Eos, Trans. Amer. Geophys. Union, 81, 121, 125.

Stokes, M. A., and T. L. Smiley, 1968: An Introduction to Tree-Ring Dating. University of Chicago Press, 73 pp.

Trenberth, K. E., G. W. Branstator, and P. A. Arkin, 1988: Origins of the 1988 North American drought. Science, 242, 1640-1645.

Woodhouse, C. A., and P. A. Kay, 1990: The use of tree-ring chronologies to show spatial and temporal changes in an air mass boundary. Phys. Geogr., 11, 172-190.

—_ and J. T. Overpeck, 1998: 2000 years of drought variability in the central United States. Bull. Amer. Meteor. Soc., 79, 2693 2714.

— J. J. Lukas, and P. M. Brown, 2002: Drought in the western Great Plains, 1845-56. Bull. Amer. Meteor. Soc., 83, 1485-1493. 
Copyright of Journal of Climate is the property of American Meteorological Society and its content may not be copied or emailed to multiple sites or posted to a listserv without the copyright holder's express written permission. However, users may print, download, or email articles for individual use. 